\title{
Evidence of illegal catch in the benthic artisanal fisheries of central Chile: patterns across species and management regimes
}

\author{
Miriam Fernández ${ }^{1}$, Michael Kriegl ${ }^{1,2,3}$, Vladimir Garmendia ${ }^{1}$ \\ Ainara Aguilar ${ }^{1}$ \& María Dulce Subida ${ }^{1}$ \\ ${ }^{1}$ Núcleo Milenio Centro de Conservación Marina CCM, Estación Costera de Investigaciones \\ Marinas ECIM, Departamento de Ecología, Facultad de Ciencias Biológicas \\ Pontificia Universidad Católica de Chile, Santiago, Chile \\ ${ }^{2}$ Faculty of Science and Engineering, Sorbonne Université, Paris, France \\ ${ }^{3}$ Bremen Marine Ecology (BreMarE), University of Bremen, Bremen, Germany \\ Corresponding author: Miriam Fernández (mfernandez@ bio.puc.cl)
}

\begin{abstract}
Non-compliance with fishing regulations is a widespread phenomenon in fisheries worldwide, jeopardizing the recovery of stocks and ecosystem services. There is an urgent need to fill the gaps in our understanding of the scale and nature of illegal fishing in artisanal fisheries, balancing the advances made in industrial fisheries. We explored patterns of fisher compliance with the existing minimum legal size (MLS) regulation in the small-scale benthic fisheries of central Chile. We focus on two of the most conspicuous species (loco Concholepas concholepas and keyhole limpets Fissurella spp.) and comparing two management regimes: management areas (MAs; local name for territorial use rights for fisheries) and open access areas (OAAs; no spatial entry restrictions). We also evaluated the effect of the spatial distribution of MAs, which determines the availability of OAAs on compliance. For both species, we measured the size of individuals in the catch in two consecutive years. We developed an index that accounts for the availability of open access areas per fisher. We found that a) the number of undersized individuals in the catch in OAAs is enormous, b) management regime influences both the median size and fraction of the undersized catch, and c) as the availability of OAAs per fisher decreases, illegal fishing increases, demonstrating the need to manage the levels of effort displacement in designing area-based instruments for management and conservation. Our findings also highlight the need to a) analyze the benefits of area-based instruments at the seascape scale, and b) develop and adapt instruments to prevent illegal fishing.
\end{abstract}

Keywords: minimum legal size; effort displacement; TURF; squeeze effect; spatial management

\section{INTRODUCTION}

Approximately $63 \%$ of the assessed marine fish stocks in the world are currently overexploited, and about half of those stocks may not be able to recover (Worm et al., 2009; Pauly \& Zeller, 2017). Stock recovery relies on management strategies and fishing regulations (Worm et al., 2009) such as bans, quotas, the prohibition of specific fishing gear and minimum landing sizes. However, scientific evidence suggests that noncompliance with fishing regulations is a widespread phenomenon in fisheries around the world (Kuperan \& Sutinen, 1998; McKinlay \& Millington, 2000; Gavin et al., 2010; Solomon et al., 2015). Illegal, unreported and unregulated (IUU) fishing accounts for an estimated $20 \%$ of the world's catch but has been reported to reach as much as 50\% in some fisheries (Agnew et al., 2009; FAO, 2017). Currently, IUU stands out as one of the most important factors contributing to fishery overexploitation, impeding the recovery of fish stocks (World Bank, 2009), compromising ecosystem function and posing a considerable threat to the sustainability of global fishery resources across the world (Agnew et al., 2009).

Despite the recent increase in governmental and scientific interest in illegal activities occurring in fishe-

Corresponding editor: Patricio Arana 
ries across the globe (e.g., Bray, 2000; Pauly \& Zeller, 2016), the characterization and assessment of illegal fishing practices in small-scale fisheries are still scarce (Cabral et al., 2018). The spatially scattered nature of small-scale fisheries imposes serious challenges to the surveillance, detection, and enforcement of non-compliant activities that facilitate IUU fishing (Drammeh, 2000; Hilborn et al., 2005; Mora et al., 2009; Worm et al., 2009; Costello et al., 2012). Small-scale fisheries, particularly those with unassessed stocks, are in a condition far worse than their industrial counterparts (Costello et al., 2012). Therefore, there is an urgent need to fill the gaps in our understanding of the scale and nature of IUU in artisanal fisheries (González et al., 2006; Salas et al., 2007; Raemaekers et al., 2011; Aburto et al., 2013), as an opportunity to promote sustainability and maximize revenues for fishers (Neubauer et al., 2013). Mitigating and counteracting the effects of illegal activities, however, is difficult without detailed information on the character of illegal fishing and reliable estimates of non-compliance rates with existing regulations (Blank \& Gavin, 2009).

Chile hosts one of the most productive coastal ecosystems in the world, ranking among the top 15 contributors to the global catch (FAO, 2018). However, there has been a persistent decline in Chile's contribution to the world's catch, a trend that correlates with the decrease in abundance of the majority of main stocks (FAO, 2018; SUBPESCA, 2019). As industrial landing declined, artisanal fisheries increased in relative importance, currently accounting for as much as $57 \%$ of the total catch (excluding aquaculture) (SERNAPESCA, 2016). However, signs of intensive effort and illegal catch in artisanal fisheries in Chile are becoming evident (Andreu-Cazenave et al., 2017; Nahuelhual et al., 2018; Oyanedel et al., 2018).

Among artisanal fisheries, the benthic fishery is particularly important, both socially and economically (Castilla \& Fernández, 1998; Fernández \& Castilla, 2005; Poblete et al., 2013; Stotz, 2018). Several regulations have been established over the last 30 years for the different resources targeted by benthic fisheries, including temporal reproductive bans, fishing quotas, diver registration to regulate effort and minimum legal size (MLS). Probably the most novel and significant management measure was the area-based comanagement program that assigns territories to fisher organizations (territorial use rights for fisheries, TURFs, called "management areas" in Chile). More than 500 management areas (MAs) are currently in place along the Chilean coastline, targeting different resources, the most important being the loco (Concholepas concholepas), the sea urchin (Loxechinus albus) and keyhole limpets (Fissurella spp.) (Leiva \& Castilla,
2002). The traditional open access areas (OAAs) regime coexists alongside the MAs system. It still constitutes a substantial fraction of the fishing grounds in central Chile, where artisanal fisheries operate (Beckensteiner et al., 2019). As a consequence, a clear mosaic of abundance and size of benthic resources is observed, with enhanced density and size in MAs (Gelcich et al., 2012; Pérez-Matus et al., 2017). Remarkably, patterns of the enhanced abundance observed in MAs compared to OAAs across the target species include the loco (Gelcich et al., 2012), which has been under a permanent ban for more than two decades. These results along with comparative studies that demonstrate that the mortality rate of the loco in OAAs is twice as high as the one estimated in MAs (Andreu-Cazenave et al., 2017) suggest illegal fishing (Badin \& Quiñones, 2014; Andreu-Cazenave et al., 2017; Oyanedel et al., 2018). Although scientists have recently begun to assess the magnitude of IUU fishing in Chilean benthic fisheries (Andreu-Cazenave et al., 2017; Oyanedel et al., 2018), we still know very little about IUU in the benthic fisheries and the cascading effects on coastal ecosystems.

The observed scale of IUU in Chilean benthic fisheries concerning one regulation (spatial ban) allows us to predict that such a pattern may extend to other critical regulations (e.g., reproductive bans, MLS). Non-compliance with MLS is a widespread phenomenon in global fisheries (e.g., Stratoudakis et al., 1998; Maguire, 2001; Catchpole et al., 2002), including benthic fisheries (e.g., Nielsen \& Mathiesen, 2003; Tewfik \& Béné, 2004). Small-scale fisheries are potentially more prone to violations to MLS due to the inherent nature of the operation (Veiga et al., 2016). However, the scientific evidence available in Chile suggests that more than $90 \%$ of fishers claimed to follow the existing size limits for benthic resources (based on interviews) (Gelcich et al., 2009). We explored patterns of fisher compliance with the current MLS regulation in artisanal benthic fisheries. We are focusing on two of the most conspicuous species, the loco (also known as Chilean abalone) and keyhole limpets, comparing two management regimes, MAs and OAAs, along $500 \mathrm{~km}$ of the coast of central Chile. The specific goals were:

a) assess median size and the fraction of individuals smaller than the MLS for loco and keyhole limpets caught by fishers in the study area while comparing the influence of management regime (MA vs. OAA) on compliance levels.

b) evaluate the potential effect of the spatial distribution of MAs, which in turn determines the availability of OAAs, on the compliance with the MLS. 
Based on existing patterns of compliance with the spatial loco ban and greater enforcement in MAs, we predict a higher proportion of individuals below the MLS in OAA fishing grounds when compared to MAs, particularly for the most valuable resource (loco). We also predict a higher percentage of undersized individuals in catches from OAAs in regions exhibiting a high abundance of MAs due to the "fisheries squeeze effect," reported in the context of marine protected areas (Attwood \& Bennett, 1995; Bohnsack, 2000; Halpern et al., 2004). We also explored the relationship between the two fisheries as well as between the two management regimes in terms of compliance levels to evaluate if some fishing locations (coves) were particularly prone to violation of the MLS regulation, regardless of the management regime or species.

\section{MATERIALS AND METHODS}

\section{Background information}

Chilean artisanal fisheries operate within five nautical miles from the coast. They use boats less than $12 \mathrm{~m}$ in length to target a diversity of algae, fish and invertebrate species (Ley General de Pesca, 2013). The artisanal fishery is of paramount importance for the country's economy, with annual total artisanal landings consistently exceeding industrial reported catch since 2008 (SERNAPESCA, 2016). There are about 100,000 artisanal fishers registered in Chile, with a small fraction $(12,000)$ enlisted as divers exploiting benthic shellfish and macroalgae (SERNAPESCA, 2016).

Artisanal fisheries in Chile are mostly organized around fishing coves locally known as "caletas," which serve as operational bases for the local artisanal fleet and fisher organizations (one or more fisher organizations can operate in each cove) (Castilla \& Gelcich, 2008). The benthic artisanal fisheries generally operate around $17 \mathrm{~km}$ away from the coves (Ruano et al., 2017; Beckensteiner et al., 2019) in harvesting grounds under two contrasting management regimes: a) exclusive harvest rights assigned to fisher organizations (territorial use rights for fisheries, TURFs), locally known as management areas (MAs) or b) historical fishing grounds without spatial entry restrictions, hereafter referred as open access areas (OAAs) (Andreu-Cazenave et al., 2017). The traditional OAA regime coexists alongside the MA system and still constitutes a substantial fraction of the fishing grounds where artisanal fisheries operate (Beckensteiner et al., 2019). Fishers officially registered in the National Service of Fisheries of Chile (SERNAPESCA) are permitted to fish in both management regimes. While some species-specific regulations operate for both management regimes (e.g., temporal reproductive bans or MLS), others apply exclusively to MAs (annual quotas) or OAAs (ban for the exploitation of loco Concholepas concholepas). Thus, locos can only be harvested legally in MAs, based on approved annual quotas. In OAAs, there is a permanent ban on the loco harvest. Fisher unions also establish specific regulations for each MA (e.g., the temporal distribution of catch).

In Chile, MLS regulations are currently in place for several benthic marine species (Resolution $\mathrm{N}^{\circ} 630 / 98$, Procedures for the Control of Minimum Sizes). The control of catches and enforcement of regulations is usually performed by SERNAPESCA and assisted by the Chilean navy and police; about 25,000 enforcement actions during 2018 focused on MLS regulations in both artisanal and industrial fleets (SERNAPESCA, 2019).

\section{Study species}

The loco and keyhole limpets (Fissurella spp.) were selected as model species for this study since both have been historically relevant for Chilean artisanal fisheries. Both resources are currently classified as fully exploited. The loco and keyhole limpets are targeted as primary resources in the management plans of the vast majority of MAs (Leiva \& Castilla, 2002; Gallardo-Fernández \& Friman, 2011; SUBPESCA, 2019). The official annual loco catch averaged $2,822 \mathrm{t}$ between 2002 and 2018, earning between USD 11.1 and 16.5 million per year. It is important to note here that, in the early 1980s, the landing was almost 10 times higher. There are 4,880 divers officially registered that hold the permit to extract loco from MAs based on preapproved quotas (SERNAPESCA, 2016). A permanent ban on extracting loco from OAAs has been in place since the early 1990s. Registration of new divers to the loco fishery is currently closed.

The keyhole limpet is a less valuable resource that emerged as a "replacement fishery" as loco abundance decreased, and regulations for loco fisheries increased in the late 1980s. Official keyhole limpet landings peaked in the early 1990s with an annual catch above $6,000 \mathrm{t}$ and have since decreased, with landings in the order of 1,000 t per year in the last five years combining OAA and MA landings. However, only a small fraction of the landing is harvested in MAs (8\% on average between 1999 and 2010) (Techeira et al., 2010). Annual revenues from keyhole limpet exportation have oscillated between USD 2.2 and 12.7 million between 2004 and 2018. A substantial number of divers $(9,394)$ are officially registered (i.e., twice the number of divers registered in loco fisheries), but diver registration for keyhole limpet fisheries has been closed since 2013 
(except in the administrative regions of Tarapacá, Antofagasta, Arica and Parinacota) (SUBPESCA, 2019).

The regulations for loco fisheries include:

a) the extractive spatial ban in OAAs established in 1993 and recently extended until 2022 (Exempt Decree $\left.\left.\mathrm{N}^{\circ} 820,2017\right), \mathrm{b}\right)$ specific annual quotas in MAs, c) a temporary reproductive ban that varies along the coast of Chile (e.g., from February $1^{\text {st }}$ to June $31^{\text {st }}$, in Atacama, Coquimbo and Valparaíso administrative regions) (Exempt Decree No409/2003), and d) the MLS set at $10 \mathrm{~cm}$ of peristome length (Exempt Decree $\mathrm{N}^{\circ} 264,1988$ ).

The $10 \mathrm{~cm}$ length can be reached at 3 to 6 years of benthic life (Manríquez et al., 2008). Fewer regulations are in place for keyhole limpet fisheries. In 1996 the MLS of $6.5 \mathrm{~cm}$ for shell length was established. Although keyhole limpets are comprised of a group of several species with differing maximum shell lengths, only a single MLS exists. In accordance, keyhole limpets are generally caught and offered on the market regardless of their taxonomic position within the genus Fissurella (Andreu-Cazenave et al., 2017). Neither spatial nor temporal extractive bans are currently in place (except for the southern administrative region de Los Lagos, at Ancud Bay), and quota limits are set only in MAs.

\section{Study area and sampling protocol}

A field study was conducted between October 2017 and July 2018, covering 12 coves for loco samplings and 13 coves for keyhole limpet samplings, to assess the influence of management regime on the fraction of undersized individuals in the central Chilean loco and keyhole limpet fisheries. Our study is based on the knowledge that illegal fishing is a widespread phenomenon in artisanal benthic fisheries (Oyanedel et al., 2018). The study areas were located between $29^{\circ} 27^{\prime} \mathrm{S}$ and $33^{\circ} 22^{\prime} \mathrm{S}$, encompassing $515 \mathrm{~km}$ of coastline and two administrative regions (Coquimbo and Valparaíso) of central Chile (Fig. 1). A Google Earth layer provided by the Undersecretary of Fisheries of the Chilean Government (SUBPESCA: http://www. subpesca.cl/portal/619/w3-article-79986.html) was used to select coves within the study region with operative MAs that declared loco and keyhole limpets as the main target resources.

For each cove, one artisanal fishers association was selected after presenting the goals of the study to the leaders and discussing the collaborative framework. Fishers were informed of our permit to conduct this study and that we did not represent any enforcement agency. Upon the organization's approval and consent to collaborate, the sampling protocol was defined so that fishers understood that we did not expect any specific operation for our study, but to be able to measure the catch of a regular fishing trip to an OAA and an MA. We offered to pay the fishers for their fishing trip to have our observers aboard and to assure paired samples (OAA and MA) in each cove. However, some fishers did not accept any payment for some of the trips (26\% for loco and 16\% for keyhole sampling trips), as these trips were part of their regular activity. No differences were found in size distribution of catches between the two sample groups (with and without payment), neither for loco (PERMANOVA: pseudo-F $=0.79, P=0.493$ ) nor for keyhole limpets (PERMANOVA: pseudo-F $=0.51, P=0.651$ ). Fishing trips were scheduled depending on favorable weather conditions.

Different sites were sampled within a cove. We refer to the site as the spatial point where the sampling took place, regardless of the management regime (OAA and MA). At each cove (e.g., Las Conchas, Quintay), at least two sites were sampled, since a minimum of one MA and one OAA was required (e.g., for Las Conchas we sampled La Cachina MA and an adjacent OAA) (Table 1). However, if there was more than one MAs associated with the operation of a fishers association, then more sites were sampled within that cove (e.g., at Quintay, we sampled two MAs identified as A and B by the Undersecretary of Fisheries and the fisher's organization, and the adjacent OAAs) (Table 1). The sampling procedure was identical for the two management regimes (MA and OAA). For the two resources, samples were directly obtained from the catch of an artisanal semi-autonomous diver (hookah) and measured either aboard the fishing boat or at the landing beach or small-scale port.

On each fishing trip, at least 200 individuals of the catch were measured for each species, following the protocol presented by Andreu-Cazenave et al. (2017). The sample size differed among sites because all individuals in the fishing bags were measured until reaching the minimum sample size (Table 1). After that, subsequent bags containing target species were not measured. The size of locos and keyhole limpets was measured to the nearest mm using a Vernier caliper. For loco, we measured the peristomal length (i.e., the distance between the external border of the siphonal canal and the extreme opposite of the shell). For keyhole limpets, we measured the total length of the shell. Besides the individual lengths, the research team aboard the boat recorded the GPS coordinates of the specific fishing site of the catch.

\section{The index of open areas availability (IAOA)}

Spatial restrictions to traditional fishing grounds following placement of TURFs or MPAs might result in 


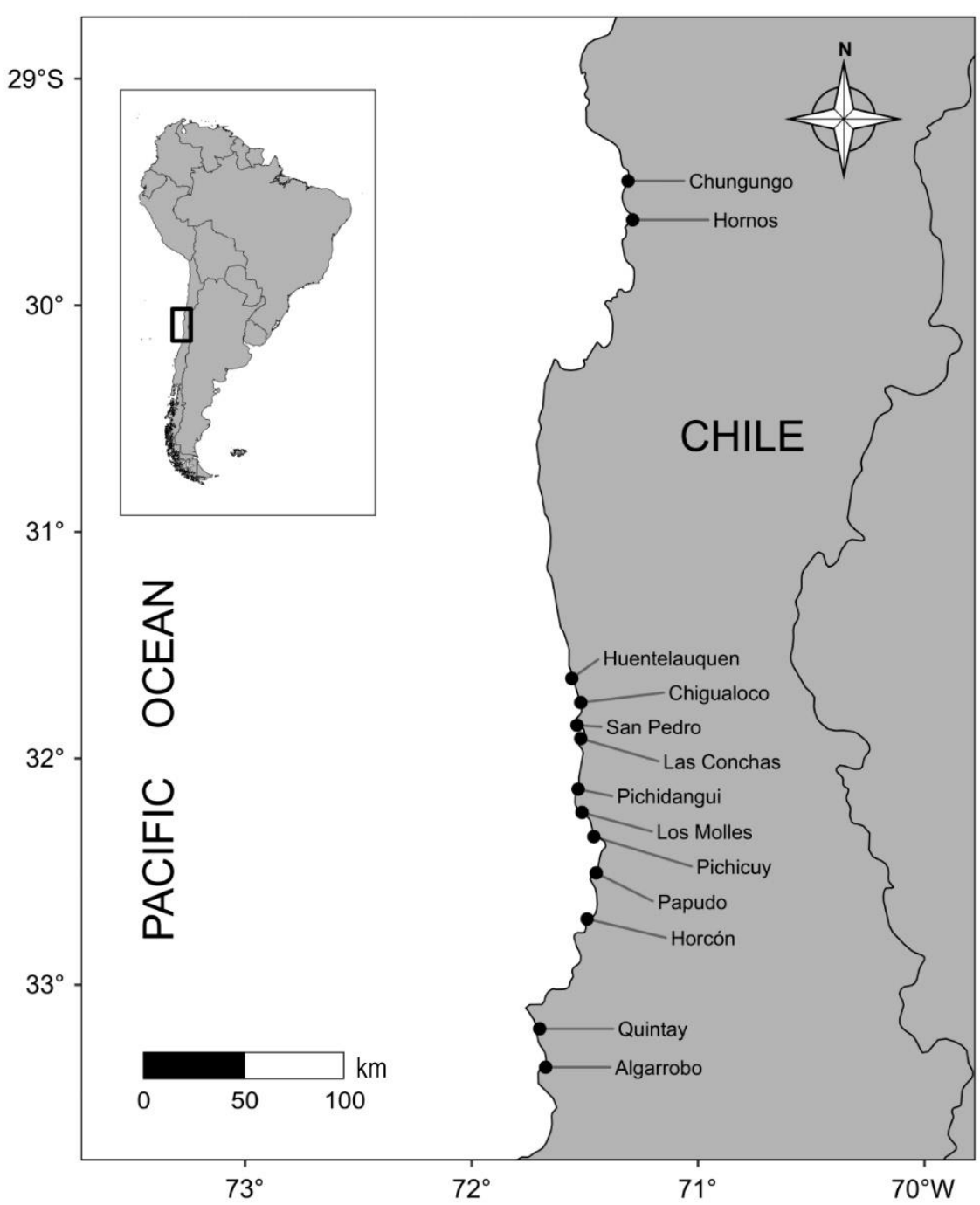

Figure 1. Map of the study region. Distribution of coves sampled along approximately $500 \mathrm{~km}$ of the coast of central Chile. At each cove, both management areas and open access areas were sampled.

fishing effort displacement to other areas (Murawski et al., 2005; Abbott \& Haynie, 2012). The impact of MAs on the catch in OAAs along the coast of Chile appears to be weak, but negative and growing over time (Beckensteiner et al., 2019). In any case, the signs of benthic resource depletion in the region's OAAs are unquestionably evident (Gelcich et al., 2012; AndreuCazenave et al., 2017; Pérez-Matus et al., 2017). The evidence of effort displacement to OAAs based on almost 200 MAs (Beckensteiner et al., 2019) does not account for the spatial variability in the fraction of the coast assigned to TURFs. As the fraction of the coast in MAs increases, and therefore the availability of space for OAAs decreases, effort displacement towards OAAs is expected to be higher. We tested the hypothesis that there is a higher proportion of undersized individuals in OAAs in coastal sectors with more fishing areas allocated to MAs. Since we lack information on fishing effort in OAAs, the index of availability of open areas (IAOA) was developed to measure the proportion of OAAs available for benthic fishing activities around each cove. The factors determining fishing effort displacement in artisanal fisheries are mostly related to the availability of alternative fishing grounds set by habitat preferences of the target species (E Costa et al., 2013) and distance to port (Stelzenmüller et al., 2008; Forcada et al., 2010). Therefore, the estimation of the IAOA for a given cove takes into account the following:

1) Fishing effort density, measured as the number of divers officially registered in the cove (DORc) plus the number of officially registered divers from neighbor coves (DORn). The latter incorporates a penalty for distance from the port since the DORs in one cove are 
Table 1. Results from the Wilcoxon rank tests (W) comparing medians of the global and undersized catch of loco (Concholepas concholepas) and keyhole limpets (Fissurella spp.) between management regimes (MA indicates management areas and OAA open access areas) at each sampling site from north to south. $\mathrm{N}$ indicates sample size and includes the percentage of undersized individuals (rounded) for each species. The index of availability of open areas is shown between parentheses for each cove. L-IAOA and H-IAOA indicate low and high index of availability of open access, respectively. $P$-values are shown between parenthesis and values $<0.05$ in bold.

\begin{tabular}{|c|c|c|c|c|c|c|c|}
\hline \multirow[b]{2}{*}{ Cove } & \multirow[b]{2}{*}{ Site } & \multicolumn{3}{|c|}{ Loco } & \multicolumn{3}{|c|}{ Keyhole limpet } \\
\hline & & $\begin{array}{l}\mathrm{n} \text { total }(\mathrm{n} \text { and } \\
\text { percentage } \\
\text { undersized) }\end{array}$ & $\begin{array}{l}\text { W statistic for } \\
\text { the catch } \\
(P \text {-value })\end{array}$ & $\begin{array}{l}\text { W statistic for the } \\
\text { undersized catch } \\
(P \text {-value })\end{array}$ & $\begin{array}{l}\mathrm{n} \text { total }(\mathrm{n} \text { and } \\
\text { percentage } \\
\text { undersized) }\end{array}$ & $\begin{array}{l}\text { W statistic } \\
\text { for the catch } \\
(P \text {-value })\end{array}$ & $\begin{array}{l}\text { W statistic for the } \\
\text { undersized catch } \\
(P \text {-value })\end{array}$ \\
\hline \multirow[t]{4}{*}{$\begin{array}{l}\text { Chungungo } \\
(0.025 ; \text { L-IAOA })\end{array}$} & MA- Chungungo E & - & - & - & $\begin{array}{c}271 \\
(167 ; 62 \%)\end{array}$ & $\begin{array}{c}19143 \\
(7.177 \mathrm{e}-10)\end{array}$ & $\begin{array}{c}6345 \\
(0.09745)\end{array}$ \\
\hline & MA-Sector D & - & - & - & $\begin{array}{c}210 \\
(149 ; 71 \%)\end{array}$ & $\begin{array}{c}13124 \\
(7.108 \mathrm{e}-13)\end{array}$ & $\begin{array}{c}6015.5 \\
(0.3571) \\
\end{array}$ \\
\hline & MA-Temblador & - & - & - & $\begin{array}{c}257 \\
(66 ; 26 \%)\end{array}$ & $\begin{array}{c}30382 \\
(0.01919)\end{array}$ & $\begin{array}{c}3380.5 \\
(0.06051)\end{array}$ \\
\hline & OAA & - & - & - & $\begin{array}{c}210 \\
(87 ; 41 \%)\end{array}$ & - & - \\
\hline \multirow[t]{3}{*}{$\begin{array}{l}\text { Hornos } \\
(0.035 ; \text { L-IAOA })\end{array}$} & MA-Hornos & $\begin{array}{c}215 \\
(2 ; 1 \%)\end{array}$ & $\begin{array}{c}43801 \\
(2.2 \mathrm{e}-16)\end{array}$ & - & $\begin{array}{c}211 \\
(0 ; 0 \%) \\
\end{array}$ & $\begin{array}{c}39924 \\
(<2.2 \mathrm{e}-16)\end{array}$ & - \\
\hline & MA-Hornos B & $\begin{array}{c}223 \\
(0 ; 0 \%)\end{array}$ & $\begin{array}{c}45872 \\
(2.2 \mathrm{e}-16)\end{array}$ & - & $\begin{array}{c}263 \\
(21 ; 8 \%) \\
\end{array}$ & $\begin{array}{c}44646 \\
(<2.2 \mathrm{e}-16)\end{array}$ & $\begin{array}{c}2493 \\
(4.02 \mathrm{e}-08)\end{array}$ \\
\hline & OAA & $\begin{array}{c}210 \\
(191 ; 86 \%)\end{array}$ & - & - & $\begin{array}{c}201 \\
(136 ; 68 \%)\end{array}$ & - & - \\
\hline \multirow[t]{2}{*}{$\begin{array}{l}\text { Huentelauquen } \\
(0.048 ; \text { L-IAOA })\end{array}$} & MA-Huentelauquen & $\begin{array}{c}289 \\
(0 ; 0 \%)\end{array}$ & $\begin{array}{c}48788 \\
(2.2 \mathrm{e}-16)\end{array}$ & - & $\begin{array}{c}225 \\
(17 ; 8 \%)\end{array}$ & $\begin{array}{c}22904 \\
(0.288)\end{array}$ & $\begin{array}{c}199.5 \\
(0.9237)\end{array}$ \\
\hline & OAA & $\begin{array}{c}218 \\
(0 ; 0 \%)\end{array}$ & - & - & $\begin{array}{c}192 \\
(23 ; 12 \%)\end{array}$ & - & - \\
\hline \multirow[t]{4}{*}{$\begin{array}{l}\text { Chigualoco } \\
(0.038 ; \text { L-IAOA })\end{array}$} & MA-Chigualoco & $\begin{array}{c}253 \\
(34 ; 13 \%)\end{array}$ & $\begin{array}{c}39760 \\
(2.765 \mathrm{e}-09)\end{array}$ & $\begin{array}{c}1196.5 \\
(0.3607) \\
\end{array}$ & $\begin{array}{c}255 \\
(21 ; 8 \%)\end{array}$ & $\begin{array}{c}36099 \\
(1.207 \mathrm{e}-07)\end{array}$ & $\begin{array}{c}144.5 \\
(0.009493)\end{array}$ \\
\hline & MA-Boca del Barco & $\begin{array}{c}294 \\
(39 ; 13 \%)\end{array}$ & $\begin{array}{c}45440 \\
(1.017 \mathrm{e}-08)\end{array}$ & $\begin{array}{c}1872 \\
(0.05826)\end{array}$ & $\begin{array}{c}261 \\
(13 ; 5 \%)\end{array}$ & $\begin{array}{c}35964 \\
(2.935 \mathrm{e}-06)\end{array}$ & $\begin{array}{c}103 \\
(0.06901)\end{array}$ \\
\hline & MA-Chepiquilla & $\begin{array}{c}270 \\
(40 ; 15 \%)\end{array}$ & $\begin{array}{c}33788 \\
(0.4035)\end{array}$ & $\begin{array}{c}2451.5 \\
(9.564 \mathrm{e}-07)\end{array}$ & $\begin{array}{c}181 \\
(23 ; 13 \%)\end{array}$ & $\begin{array}{c}20818 \\
(0.4811)\end{array}$ & $\begin{array}{c}155 \\
(0.006386)\end{array}$ \\
\hline & OAA & $\begin{array}{c}240 \\
(79 \%)\end{array}$ & - & - & $\begin{array}{c}221 \\
(25 ; 11 \%)\end{array}$ & - & - \\
\hline \multirow[t]{3}{*}{$\begin{array}{l}\text { San Pedro } \\
(0.032 ; \text { L-IAOA })\end{array}$} & MA-Ñague & $\begin{array}{c}266 \\
(0 ; 0 \%)\end{array}$ & $\begin{array}{c}55529 \\
(2.2 \mathrm{e}-16) \\
\end{array}$ & - & $\begin{array}{c}284 \\
(27 ; 9 \%) \\
\end{array}$ & $\begin{array}{c}41984 \\
(<2.2 \mathrm{e}-16)\end{array}$ & $\begin{array}{c}681.5 \\
(0.1096) \\
\end{array}$ \\
\hline & MA-Ñague B & $\begin{array}{c}325 \\
(17 ; 5 \%)\end{array}$ & $\begin{array}{c}68411 \\
(2.2 \mathrm{e}-16)\end{array}$ & $\begin{array}{c}2357.5 \\
(0.0001848)\end{array}$ & $\begin{array}{c}204 \\
(12 ; 6 \%)\end{array}$ & $\begin{array}{c}29778 \\
(1.185 \mathrm{e}-13)\end{array}$ & $\begin{array}{c}222.5 \\
(0.6246)\end{array}$ \\
\hline & OAA & $\begin{array}{c}227 \\
(179 ; 79 \%)\end{array}$ & - & - & $\begin{array}{c}205 \\
(41 ; 20 \%) \\
\end{array}$ & - & - \\
\hline \multirow[t]{3}{*}{$\begin{array}{l}\text { Las Conchas } \\
(0.033 ; \text { L-IAOA })\end{array}$} & MA-La Cachina & $\begin{array}{c}340 \\
(0 ; 0 \%)\end{array}$ & $\begin{array}{c}70490 \\
(2.2 \mathrm{e}-16)\end{array}$ & & $\begin{array}{c}241 \\
(0 ; 0 \%)\end{array}$ & $\begin{array}{c}52041 \\
(<2.2 \mathrm{e}-16)\end{array}$ & - \\
\hline & MA-Sector C & $\begin{array}{c}230 \\
(40 ; 17 \%)\end{array}$ & $\begin{array}{c}43768 \\
(2.2 \mathrm{e}-16)\end{array}$ & $\begin{array}{c}5033.5 \\
(5.145 \mathrm{e}-06)\end{array}$ & $\begin{array}{c}207 \\
(71 ; 34 \%)\end{array}$ & $\begin{array}{c}32832 \\
(9.612 \mathrm{e}-06)\end{array}$ & $\begin{array}{c}5778 \\
(0.02636)\end{array}$ \\
\hline & OAA & $\begin{array}{c}213 \\
(172 ; 81 \%)\end{array}$ & - & - & $\begin{array}{c}256 \\
(137 ; 53 \%)\end{array}$ & - & - \\
\hline \multirow[t]{2}{*}{$\begin{array}{l}\text { Pichidangui } \\
(0.120 ; \mathrm{H}-\mathrm{IAOA})\end{array}$} & MA- Pichidangui & $\begin{array}{c}240 \\
(38 ; 16 \%)\end{array}$ & $\begin{array}{c}40168 \\
(8.6 e-11)\end{array}$ & $\begin{array}{c}3007.5 \\
0.0007618)\end{array}$ & $\begin{array}{c}224 \\
(0 ; 0 \%)\end{array}$ & $\begin{array}{c}55114 \\
(<2.2 \mathrm{e}-16)\end{array}$ & - \\
\hline & OAA & $\begin{array}{c}250 \\
(116 ; 46 \%)\end{array}$ & - & - & $\begin{array}{c}250 \\
(0 ; 0 \%)\end{array}$ & - & - \\
\hline \multirow[t]{3}{*}{$\begin{array}{l}\text { Los Molles } \\
(0.100 ; \text { H-IAOA })\end{array}$} & MA-Los Molles & $\begin{array}{c}206 \\
(26 ; 13 \%)\end{array}$ & $\begin{array}{c}24565 \\
(0.0007967)\end{array}$ & $\begin{array}{c}1366 \\
(0.00374)\end{array}$ & $\begin{array}{c}272 \\
(51 ; 19 \%)\end{array}$ & $\begin{array}{c}40408 \\
(3.348 \mathrm{e}-14)\end{array}$ & $\begin{array}{c}3788.5 \\
(1.468 \mathrm{e}-05)\end{array}$ \\
\hline & MA-Playa Los Molles & $\begin{array}{c}250 \\
(0 ; 0 \%)\end{array}$ & $\begin{array}{c}42077 \\
(2.2 \mathrm{e}-16)\end{array}$ & - & $\begin{array}{c}322 \\
(43 ; 13 \%)\end{array}$ & $\begin{array}{c}51168 \\
(<2.2 \mathrm{e}-16)\end{array}$ & $\begin{array}{c}3071 \\
(0.0003701)\end{array}$ \\
\hline & OAA & $\begin{array}{c}200 \\
(76 ; 38 \%)\end{array}$ & - & - & $\begin{array}{c}212 \\
(104 ; 49 \%)\end{array}$ & - & - \\
\hline \multirow[t]{2}{*}{$\begin{array}{l}\text { Pichicuy } \\
(0.144 ; \mathrm{H}-\mathrm{IAOA})\end{array}$} & MA-Pichicuy & $\begin{array}{c}255 \\
(31 ; 12 \%)\end{array}$ & $\begin{array}{c}37366 \\
(3.082 \mathrm{e}-07)\end{array}$ & $\begin{array}{l}1386.5 \\
(0.153)\end{array}$ & $\begin{array}{c}250 \\
(28 ; 11 \%)\end{array}$ & $\begin{array}{c}45290 \\
(<2.2 \mathrm{e}-16)\end{array}$ & $\begin{array}{c}305.5 \\
(2.299 \mathrm{e}-06)\end{array}$ \\
\hline & OAA & $\begin{array}{c}231 \\
(76 ; 33 \%)\end{array}$ & - & - & $\begin{array}{c}240 \\
(59 ; 25 \%)\end{array}$ & - & - \\
\hline \multirow[t]{3}{*}{$\begin{array}{l}\text { Papudo } \\
(0.189 ; \text { H-IAOA })\end{array}$} & MA-Papudo & $\begin{array}{c}238 \\
(20 ; 8 \%)\end{array}$ & $\begin{array}{c}41410 \\
(2.2 \mathrm{e}-16)\end{array}$ & $\begin{array}{c}2826.5 \\
(2.506 \mathrm{e}-10)\end{array}$ & $\begin{array}{c}255 \\
(2 ; 1 \%)\end{array}$ & $\begin{array}{c}35973 \\
(5.339 \mathrm{e}-14)\end{array}$ & $\begin{array}{c}29 \\
(0.9666)\end{array}$ \\
\hline & MA-Punta Pite & $\begin{array}{c}214 \\
(18 ; 8 \%)\end{array}$ & $\begin{array}{c}37098 \\
(2.2 \mathrm{e}-16)\end{array}$ & $\begin{array}{c}2532.5 \\
(2.244 \mathrm{e}-09)\end{array}$ & $\begin{array}{c}217 \\
(8 ; 4 \%)\end{array}$ & $\begin{array}{c}32034 \\
(<2.2 \mathrm{e}-16)\end{array}$ & $\begin{array}{c}85 \\
(0.3115) \\
\end{array}$ \\
\hline & OAA & $\begin{array}{c}200 \\
(151 ; 75 \%)\end{array}$ & - & - & $\begin{array}{c}200 \\
(28 ; 14 \%)\end{array}$ & - & - \\
\hline
\end{tabular}


continuation

\begin{tabular}{|c|c|c|c|c|c|c|c|}
\hline \multirow[b]{2}{*}{ Cove } & \multirow[b]{2}{*}{ Site } & \multicolumn{3}{|c|}{ Loco } & \multicolumn{3}{|c|}{ Keyhole limpet } \\
\hline & & $\begin{array}{l}\mathrm{n} \text { total ( } \mathrm{n} \text { and } \\
\text { percentage } \\
\text { undersized) }\end{array}$ & $\begin{array}{l}\text { W statistic for } \\
\text { the catch } \\
(P \text {-value })\end{array}$ & $\begin{array}{l}\text { W statistic for the } \\
\text { undersized catch } \\
\text { ( } P \text {-value) }\end{array}$ & $\begin{array}{l}\mathrm{n} \text { total ( } \mathrm{n} \text { and } \\
\text { percentage } \\
\text { undersized) }\end{array}$ & $\begin{array}{l}\text { W statistic } \\
\text { for the catch } \\
(P \text {-value })\end{array}$ & $\begin{array}{l}\text { W statistic for the } \\
\text { undersized catch } \\
(P \text {-value })\end{array}$ \\
\hline \multirow[t]{2}{*}{$\begin{array}{l}\text { Horcón } \\
(0.131 ; \mathrm{H}-\mathrm{IAOA})\end{array}$} & MA-Horcón & $\begin{array}{c}242 \\
(4 ; 2 \%) \\
\end{array}$ & $\begin{array}{c}30855 \\
(6.399 \mathrm{e}-08) \\
\end{array}$ & $\begin{array}{c}205.5 \\
(0.01418) \\
\end{array}$ & $\begin{array}{c}220 \\
(27 ; 13 \%) \\
\end{array}$ & $\begin{array}{c}40352 \\
(<2.2 \mathrm{e}-16)\end{array}$ & $\begin{array}{c}2699 \\
(1.713 \mathrm{e}-05)\end{array}$ \\
\hline & OAA & $\begin{array}{c}212 \\
(59 ; 28 \%)\end{array}$ & - & - & $\begin{array}{c}222 \\
(131 ; 59 \%)\end{array}$ & - & - \\
\hline \multirow[t]{3}{*}{$\begin{array}{l}\text { Quintay } \\
(0.345 ; \mathrm{H}-\mathrm{IAOA})\end{array}$} & MA-Sector A & $\begin{array}{c}232 \\
(9 ; 4 \%)\end{array}$ & $\begin{array}{c}25748 \\
(0.03329)\end{array}$ & $\begin{array}{c}273.5 \\
(0.03764)\end{array}$ & $\begin{array}{c}215 \\
(0 ; 0 \%)\end{array}$ & $\begin{array}{c}31031 \\
(1.798 \mathrm{e}-08)\end{array}$ & - \\
\hline & MA-Sector B & $\begin{array}{c}250 \\
(0 ; 0 \%)\end{array}$ & $\begin{array}{c}37236 \\
(0.0002109)\end{array}$ & - & $\begin{array}{c}245 \\
(3 ; 1 \%)\end{array}$ & $\begin{array}{c}35041 \\
(2.237 \mathrm{e}-08)\end{array}$ & $\begin{array}{c}5.5 \\
(0.1625) \\
\end{array}$ \\
\hline & OAA & $\begin{array}{c}250 \\
(42 ; 17 \%)\end{array}$ & - & - & $\begin{array}{c}220 \\
(9 ; 4 \%)\end{array}$ & - & - \\
\hline \multirow[t]{3}{*}{$\begin{array}{l}\text { Algarrobo } \\
(0.116 ; \mathrm{H}-\mathrm{IAOA})\end{array}$} & MA-Sector A & $\begin{array}{c}207 \\
(51 ; 25 \%)\end{array}$ & $\begin{array}{l}23208 \\
(0.446)\end{array}$ & $\begin{array}{c}1539.5 \\
(0.5987)\end{array}$ & $\begin{array}{c}303 \\
(20 ; 7 \%)\end{array}$ & $\begin{array}{c}31226 \\
(9.105 \mathrm{e}-09)\end{array}$ & $\begin{array}{c}328 \\
(0.006747)\end{array}$ \\
\hline & MA-Sector C & $\begin{array}{c}200 \\
(16 ; 8 \%)\end{array}$ & $\begin{array}{c}19490 \\
(0.09984)\end{array}$ & $\begin{array}{l}830.5 \\
(6 e-07)\end{array}$ & $\begin{array}{c}204 \\
(5 ; 2 \%)\end{array}$ & $\begin{array}{c}39626 \\
(4.027 \mathrm{e}-12)\end{array}$ & $\begin{array}{c}79.5 \\
(0.1339)\end{array}$ \\
\hline & OAA & $\begin{array}{c}215 \\
(57 ; 26 \%)\end{array}$ & - & - & $\begin{array}{c}284 \\
(22 ; 8 \%)\end{array}$ & - & - \\
\hline
\end{tabular}

expected to fish more often in fishing areas that are closer to the port of their cove than in areas closer to the port of neighbor coves (Ruano et al., 2017). We set a $17 \mathrm{~km}$ cutoff around the landing port (cove) (Beckensteiner et al., 2019) and a diving depth limit of $20 \mathrm{~m}$ to represent the accessible habitat of the target species (with no depth penalty). The $20 \mathrm{~m}$ depth limit is arbitrary and based on previous studies (Beckensteiner et al., 2019) as well as on current depth limit regulations for shellfish divers decreed by the Chilean Navy (Supreme Decree N545/2013). For MAs, we simply used the polygon of the management area, and no penalties apply since only fishers from a given organization are expected to fish in that MA.

2) The proportion of surface area under OAAs about MAs, both measured in $\mathrm{km}^{2}$, in the accessible fishing grounds of the cove (considering the $17 \mathrm{~km}$ cutoff around the port and the diving depth limit of $20 \mathrm{~m}$ ). The size of the areas assigned to OAA and MA regimes was calculated with ArcGIS (10.1 version), using the official 2018 GIS layers of MA distribution provided by the Chilean Undersecretary of Fisheries (available at http://www.subpesca.cl/portal/619/w3-article-79986. html).

Thus, for each cove, the IAOA is a proxy of the proportion of OAAs that corresponds to each officially registered diver that potentially can exert fishing effort around that cove [DOR from the cove (DORc) + neighbor coves (DORn)], calculated as follows:

$$
\mathrm{IAOA}=(\mathrm{OAA} / \mathrm{MA}) /(\mathrm{DORc}+\mathrm{DORn})
$$

Therefore, as the estimate of IAOA increases, the proportion of OAAs relative to MAs increases, and the fishing effort (measured as the number of DOR) around that cove decreases. Although the IAOA is calculated as a continuous variable, we discretized it into two categories for our analysis: high index of availability of OAAs (H-IAOA for IAOA values $>0.1$ ) and low index of availability of OAAs (L-IAOA, for IAOA values $<0.05)$. The IAOA category assigned to each studied cove is shown in Table 1 .

\section{Data analysis}

Length data (in $\mathrm{mm}$ ) recorded at each sampling site ( $\mathrm{n}=33$ for the loco, $\mathrm{n}=37$ for keyhole limpets) and cove ( $\mathrm{n}=12$ for the loco, $\mathrm{n}=13$ for keyhole limpets) was organized in a database which explicitly considers (a) management regime (two levels, MA and OAA), and (b) the index of open areas availability (IAOA) for each cove. For each cove, we built an overall sizefrequency distribution, using $0.5 \mathrm{~cm}$-sized bins. We considered and excluded outliers from the database when observations of small individuals fell in size classes preceded by more than two empty ( 0 frequency) size classes in each site's size-frequency distribution. We assumed these smaller specimens were attached to the shell of larger individuals and were therefore extracted by chance.

Whenever more than one fishing trip was completed to attain the minimum sampling size in a given site (i.e., 200 specimens), we summed the observations for all the fishing trips performed, since sampling dates were conducted within a short period (e.g., Quintay OAA). On the other hand, if the total number of observations exceeded 400 in a given site, we used a bootstrap resampling technique to end up with a size-frequency distribution of 200 observations that accurately reflected the whole size-frequency distribution of that site. 
Non-parametric Wilcoxon signed-rank tests were used to compare medians of the size distributions or percentage of the undersized catch for each target species between management regimes ( $\mathrm{W}$ will be used to indicate the Wilcoxon test statistic). Additionally, a permutational multivariate analysis of variance (PERMANOVA, Anderson et al., 2008) using $0.5 \mathrm{~cm}$ size classes as variables and Euclidean distances was also applied to test for significant effects of management regime (2 levels: MA, OAA) on the sitespecific size-frequency distributions. The Spearman rank correlation coefficient was used to assess significant monotonic relationships of non-compliance with the MLS between both management regimes and target species.

The combined effect of management regime and OAAs availability over the size composition of the global and undersized catch was assessed using generalized linear models (GLMs), as the ANOVA assumption of homoscedasticity was not always met. For each resource (loco and keyhole limpets) and size composition data (global and undersized catch), we constructed GLMs using the Gaussian family structure for errors. However, we selected the quasi-Poisson family structure for over-dispersed data and the negative binomial for highly skewed data. The adequacy of the selected error structures was assessed by visual inspection of residuals vs. fit plots, and the goodness-of-fit of the models was assessed by comparing their relative contribution to the total explained deviance. The selection of the most parsimonious model was made by first including all factors and their interactions while progressively excluding non-significant factors until the model fit was optimized. Data treatment and statistical analyses were carried out using the statistical capabilities of the programming language $\mathrm{R}$ (version 3.4.1) ( $\mathrm{R}$ Core Team, 2018). Plots were prepared using the $\mathrm{R}$ package "ggplot2".

\section{RESULTS}

\section{The pattern of the size of the catch under two management regimes}

Contrasting patterns of the size distribution of the catch were observed between MAs and OAAs for loco (PERMANOVA: pseudo-F $=12.84, \mathrm{df}=1, P=0.001$ ). The total catch of loco Concholepas concholepas is composed mostly of individuals larger than the MLS in MAs (92.6\%), while in OAAs, it spreads out over a larger range of the size spectrum, with a $47.8 \%$ of undersized individuals (that is, with a size below the MLS) (Figs. 2a-b). In fact, the median of the size distributions was significantly larger in MAs (11.05 $\mathrm{cm})$ than in OAAs $\left(10.08 \mathrm{~cm} ; \mathrm{W}=10.24 \times 10^{6}, P<\right.$ $0.001)$. A similar trend was observed in keyhole limpets Fissurella spp., with significantly different patterns of size-frequency distribution of the catch between management regimes (PERMANOVA: pseudo-F = 4.44 , df $=1, P=0.012$ ). The fraction of the total keyhole limpet catches reaching MLS was lower in OAAs (34\% of undersized individuals) than in MAs (only 15\% of undersized individuals) (Figs. 2c-d). As for loco, the median of the size distributions in MAs $(7.68 \mathrm{~cm})$ was significantly larger than that in OAAs $(6.91 \mathrm{~cm})\left(\mathrm{W}=11.41 \times 10^{6}, P<0.001\right)$.

The global pattern between management regimes is also evident at the local scale. The median sizes of the locos comprising the catch were consistently larger in MAs when compared to nearby OAAs in most cases (17 out of 21 OAA-MA paired comparisons from 10 out of 12 coves) (Table 1). Exceptions to this general pattern were observed when (a) a smaller median size was found in the MA than the nearby OAA (QuintaySector A, Table 1), and (b) no significant difference in median size between management regimes was detected (Chepiquilla and both MAs in Algarrobo) (Table 1). Significant differences in median keyhole limpet size were also found in 22 out of 24 OAA-MA paired comparisons (11 out of 13 coves), a pattern consistent across management regimes (Table 1, Fig. 3). Although in 19 of 22-paired comparisons, median keyhole limpet size was larger in MAs than in OAAs, in three cases, the reverse pattern was observed (Algarrobo-Sector A, Chungungo-Sector D and Chungungo E, Table 1). No difference in the median size of keyhole limpets was found between MA and OAA at Huentelauquen cove and Chigualoco (only for Boca del Barco) (Table 1).

\section{The pattern of the undersized fraction of the catch under two management regimes}

The global median of the size distributions of loco and keyhole limpets was also significantly lower at OAAs $($ loco $=9.0 \mathrm{~cm}$; keyhole limpets $=6.06 \mathrm{~cm})$ than in MAs $($ loco $=9.6 \mathrm{~cm}$; limpets $=6.10 \mathrm{~cm})\left(\right.$ loco: $\mathrm{W}=36.0 \times 10^{4}$, $P<0.001$; keyhole limpets: $\mathrm{W}=39.8 \times 10^{4}, P<0.001$ ) when the analysis was concentrated on the fraction of undersized catch. However, at the local scale, the median of the fraction of undersized catch did not always significantly differ between MAs and nearby OAAs (Table 1, Fig. 3). The median size was significantly different between management regimes in most cases for the loco (10 out of 14 OAA-MA paired comparisons). Still, for keyhole limpets, only 9 out of 20 paired comparisons differed (Table 1 ). The four sites exhibiting the highest percentage of undersized locos (>70\%) were OAAs (Papudo, San Pedro, Las Conchas 


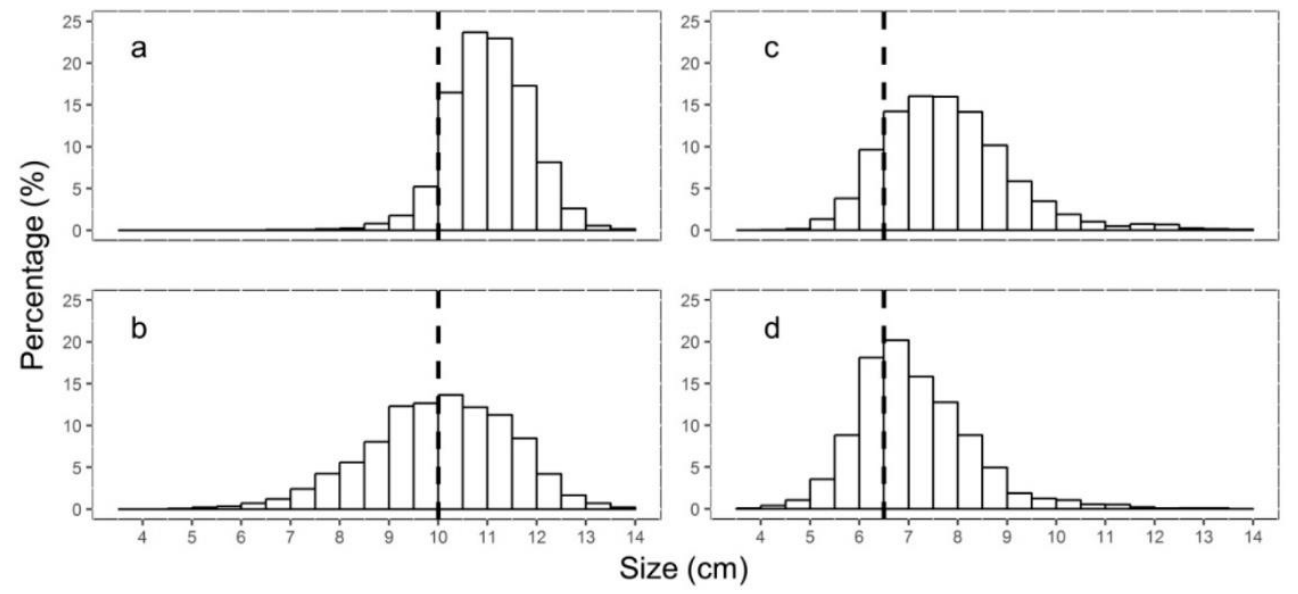

Figure 2. Relative size-frequency distribution of both resources total catch by management regime, a) loco (Concholepas concholepas) in MA, b) loco in open access areas (OAA), c) keyhole limpets (Fissurella spp.) in MA, d) keyhole limpets in OAA. The broken vertical lines indicate the minimum legal size of $10 \mathrm{~cm}$ for loco and $6.5 \mathrm{~cm}$ for keyhole limpets.

and Hornos) (Table 1). The MA showing the highest percentage of undersized locos in the catch was located at Algarrobo-Sector A, while for keyhole limpets were Chungungo-Sector D (Table 1). The OAAs at Hornos, Las Conchas, Pichidangui and Horcón also showed more than $50 \%$ of undersized keyhole limpets in the catch (Table 1). The OAAs at Las Conchas and Hornos showed the highest percentage of undersized individuals for both species.

We did not find a significant correlation between the percentange of the catch of loco and keyhole limpets under minimum legal size for MAs. (Spearman Rho $=$ $-0.098, P=0.766)$. However, a marginally significant positive trend was observed in OAAs (Spearman Rho $=0.59, P=0.046)$. The level of compliance with the MLS regulation (fraction of undersized individuals) between management regimes did not correlate, neither for the loco (Spearman Rho $=-0.17, P=0.588$ ) nor for keyhole limpets (Spearman Rho $=0.32, P=0.272$ ).

\section{Influence of availability of open access on the size distribution of the catch}

The size of locos in the global catch was significantly influenced by the availability of areas with open access to fishing among coves (Fig. 4a, GLM results in Table 2). Smaller individuals were found at OAAs around coves with low IAOA than in MAs (Table 2). In contrast, no significant difference in loco size was observed between MAs and OAAs from coves with high IAOA (Fig. 4a). The size of locos harvested from MAs did not differ across the gradient of IAOA (Fig. 4a). The size of keyhole limpets in the global catch was significantly larger in MAs than OAAs and coves with high IAOA (Fig. 4b, Table 2). Likewise, when focusing on the fraction of undersized global catch, the median size was always larger (closer to the MLS) in MAs than in OAAs and also in coves with high IAOA when compared than in coves with low IAOA for both species (Figs. 4c-d, Table 2). The percentage of catch below MLS for loco was significantly higher in OAAs (17-91\%) than in MAs (0-17\%), and also higher in OAAs in regions with low IAOA (33-91\%) when compared to OAAs in regions with high IAOA (17$76 \%$ ) (Fig. 5a, Table 2). The proportion of keyhole limpets below the MLS was also significantly higher in OAAs (4-67\%) than MAs (0-52\%), but no effect of open access areas availability was observed (Fig. 5b, Table 2).

\section{DISCUSSION}

Our results clearly show that illegal fishing in Chilean benthic artisanal fisheries is not only restricted to previously assessed spatial bans (Badin \& Quiñones, 2014; Andreu-Cazenave et al., 2017; Oyanedel et al., 2018) but also to MLS violations. We found that a) the fraction of illegal catch (below MLS) in OAAs is enormous, particularly for the most valuable resource (the loco Concholepas concholepas); b) behavioral changes of fishers between management regime influence both the median size and fraction of the undersized catch; c) in OAAs, the level of violation to MLS correlates between species, suggesting that fishers from some coves are more prone to harvest undersized individuals; and finally d) as the availability of OAAs interspaced with MAs per fisher decreases, illegal fishing increases, demonstrating the need to account for reasonable levels of effort displacement in designing area-based instruments for mana- 


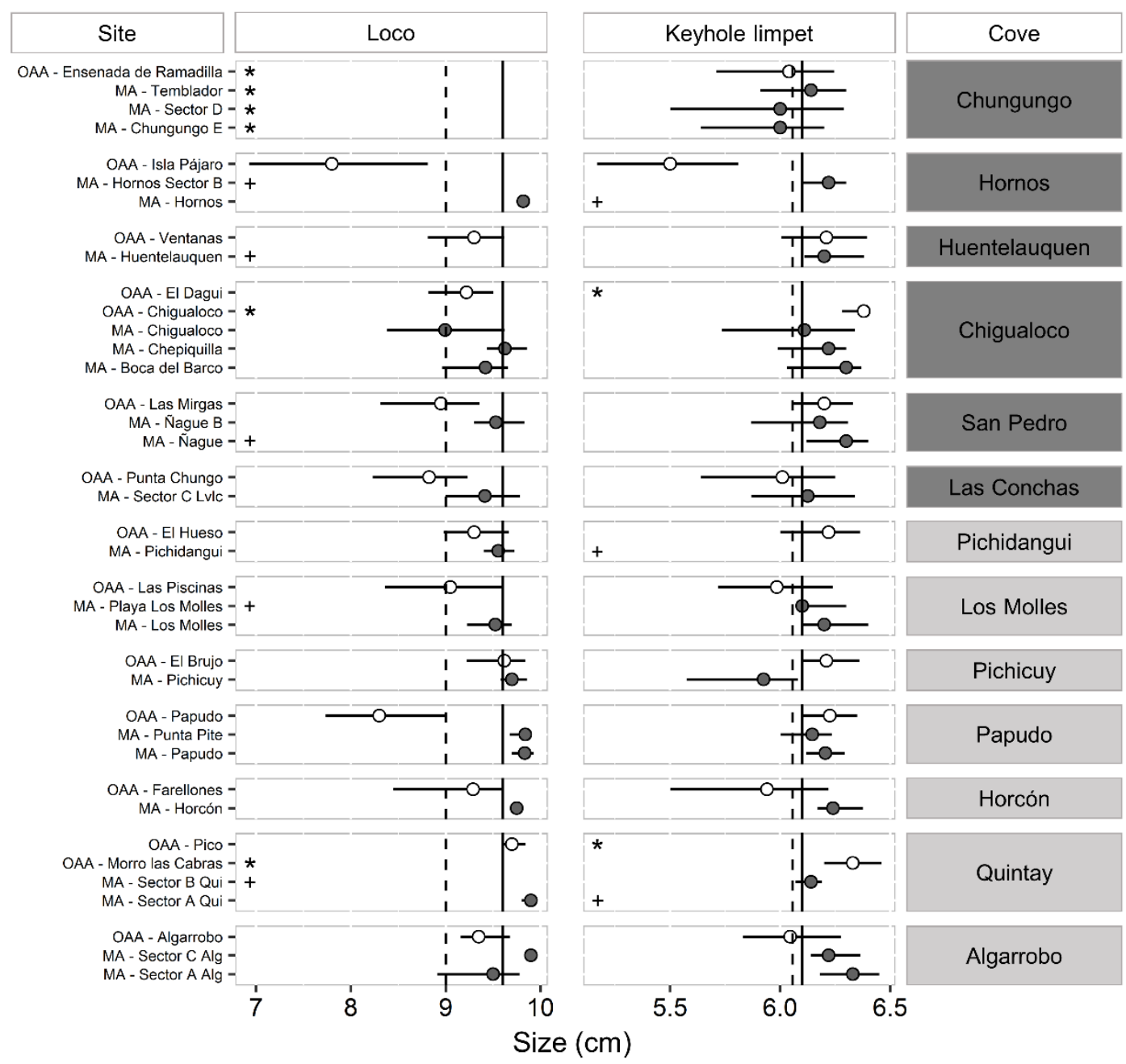

Figure 3. Median of undersized (below minimum legal size) fraction of the catch at each sampled site, from north to south, for management areas (dark grey circles) and open access areas (white circles), for loco (Concholepas concholepas) and keyhole limpets (Fissurella spp.) grouped by coves. Horizontal lines show the interquartile range. Broken vertical lines represent the overall median size for open access areas and solid vertical lines for management areas. Sites, where the catch was entirely comprised of legal-size individuals, are indicated by (+), while a lack of data for a specific sampling site is indicated by $(*)$. Dark gray rectangles indicate coves with a low index of availability of open areas (IAOA), while light gray shows the coves with high IAOA.

gement and conservation, with the end goal of preserving ecosystem function at landscape scales. Thus, this study reports a widespread phenomenon in Chile, rarely documented scientifically.

The management regime influences the size structure of the catch, median size and the fraction of the undersized catch. We show that most of the catch in MAs is composed of individuals larger than the MLS (92.6\%), which doubles the fraction of individuals legally harvested in OAAs, suggesting that enforcement in MAs is more effective to regulate fishing effort than in OAAs. Consequently, MAs offer better conditions for the recovery of exploited benthic species. Although the keyhole limpet Fissurella spp. fraction smaller than the MLS in the catch is lower than the loco, violations to the MLS in OAAs are also twice as much as in MAs, regionally. Our results suggest the urgent need to conduct studies to assess the MLS regulation for both species and the consequences of violations to existing MLS regulations on population dynamics of both species. It is important to remark that MLS of the loco is substantially larger than the age of first reproduction, potentially allowing egg production despite the harvesting of undersized individuals and illegal fishing in OAAs (Ramorino, 1979). The opposite might be the case for limpets, suffering lower 


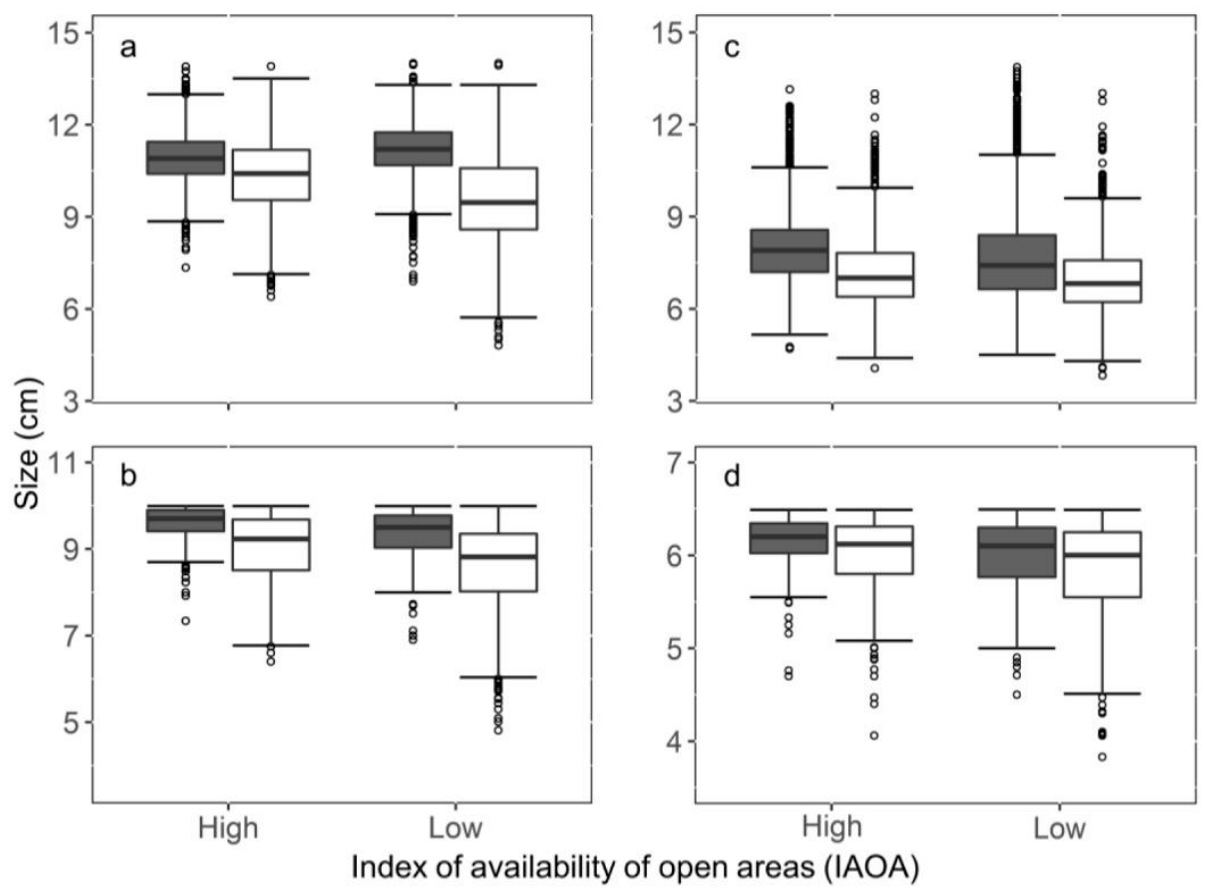

Figure 4. Boxplots showing loco's (Concholepas concholepas) and keyhole limpet's (Fissurella spp.) size, extracted at high and low open access areas availability, as defined by the index of availability of open areas (IAOA), considering: a) loco global catch, b) fraction of the catch below the minimum legal size for loco, c) keyhole limpets global catch, d) fraction of the catch below the minimum legal size for keyhole limpets. The size scale in the y-axis differs between the global and the fraction of the catch below the minimum legal size and between species. Dark grey boxplots indicate management areas and white boxplots open access areas.

levels of illegal fishing but with MLS near the age of first reproduction (Brown et al., 1997).

Comparing MA and OAA results also provides new evidence supporting the value of TURFs from different perspectives. The ecological benefit aligns with global (Lester \& Halpern, 2008; Lester et al., 2009; Sala et al., 2018) and local (Gelcich et al., 2012) evidence. However, it also includes benefits from the management perspective, improving enforcement and providing incentives for co-management, innovation and stewardship, which in the end could also give rise to direct benefits for conservation and ecosystem services (Marín et al., 2012; Gelcich et al., 2013). We claim that the pattern observed is not explained by particular conditions in MAs favoring larger sizes and abundance of exploited species, based on a set of direct and indirect pieces of evidence. One direct evidence comes from Las Cruces fully protected area, showing comparable conditions to surrounding OAAs before being closed off from exploitation in 1982 (Castilla \& Durán, 1985) and therefore suggesting that this site was similar to the background areas. Significant increases in biomass and sizes of exploited species have been reported only in management areas (since territorial user rights for fisheries have been established), suggesting that changes observed in no-take and management areas are related to changes in the management regime rather than to pre-existing conditions in studied areas (Castilla et al., 1998).

Moreover, site selection for TURFs seems to be mostly driven by the presence of historical fishing grounds in the vicinity to the cove rather than to evident variation in productivity (Gelcich et al., 2010). Fishers tend to protect MAs near to their fishing cove better due to the cost involved in patrolling (Gelcich et al., 2013). Indirect evidence for the similarity of environmental conditions in fishing grounds of both regimes comes from comparative studies examining body condition and investment in the reproduction of keyhole limpets and sea urchins (Echinoidea), which showed no differences between OAAs, MAs and protected areas (Fernández et al., 2017).

The regional-scale analysis is persistent at the cove scale, showing that, in most cases, the median sizes of the individuals comprising the catch of both species were consistently larger in MAs compared to nearby OAAs. In some of the analyzed coves, we discovered MLS violations to be particularly high. However, for keyhole limpets, only half of the coves exhibited differences in the fraction of the undersized catch 
Table 2. Generalized linear models (GLM) results relating loco (Concholepas concholepas) and keyhole limpets (Fissurella spp.) size of the global and undersized fractions of the catch, percentage $(\%)$ of undersized catch under the management regime (MR), and the index of availability of open areas (IAOA). For Gaussian and quasipoisson error families, $P>\mathrm{F}$; for negative binomial family, $P>\mathrm{Chi}^{2}$.

\begin{tabular}{|c|c|c|c|c|c|c|c|c|c|c|c|c|}
\hline & \multirow{2}{*}{$\begin{array}{l}\text { GLM models } \\
\text { Source }\end{array}$} & \multicolumn{4}{|c|}{$\begin{array}{c}\text { Size of global catch } \sim \text { MR } . \text { IAOA, } \\
\text { family = quasipoisson }\end{array}$} & \multicolumn{3}{|c|}{$\begin{array}{l}\text { Size of undersized catch } \sim \mathrm{MR}+ \\
\text { IAOA, family = gaussian }\end{array}$} & \multicolumn{4}{|c|}{$\begin{array}{l}\% \text { of undersized catch } \sim \text { MR . IAOA, } \\
\text { family }=\text { neg. binomial }\end{array}$} \\
\hline & & Intercept & MR & IAOA & MR IAOA & Intercept & MR & IAOA & Intercept & MR & IAOA & MR IAOA \\
\hline \multirow{5}{*}{$\begin{array}{l}\mathscr{0} \\
\mathscr{O} \\
0\end{array}$} & df & & 1 & 1 & 1 & & 1 & 1 & & 1 & 1 & 1 \\
\hline & Deviance & & 192.3 & 1.8 & 44.2 & & 131.1 & 62.1 & & 52.5 & 0.1 & 4.6 \\
\hline & Residual df & 7886 & 7885 & 7884 & 7883 & 1655 & 1654 & 1653 & 23 & 22 & 21 & 20 \\
\hline & Residual deviance & 1067.9 & 875.6 & 873.8 & 829.6 & 1386 & 1254.9 & 1192.8 & 87.6 & 35.0 & 35.0 & 30.4 \\
\hline & $P$ & $<0.005$ & $<0.005$ & $<0.005$ & $<0.005$ & $<0.005$ & $<0.005$ & $<0.005$ & $<0.005$ & $<0.005$ & 0.79 & 0.03 \\
\hline \multirow{7}{*}{ 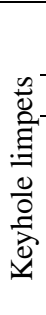 } & GLM models & \multicolumn{4}{|c|}{$\begin{array}{l}\text { Size of global catch } \sim \text { MR + IAOA, } \\
\text { family = quasipoisson }\end{array}$} & \multicolumn{3}{|c|}{$\begin{array}{l}\text { Size of undersized catch } \sim \mathrm{MR}+ \\
\text { IAOA, family = gaussian }\end{array}$} & \multicolumn{4}{|c|}{$\begin{array}{l}\% \text { of undersized catch } \sim \mathrm{MR}, \\
\text { family }=\text { neg. binomial }\end{array}$} \\
\hline & Source & Intercept & & & IAOA & Intercept & MR & IAOA & Intercept & MR & & \\
\hline & $\mathrm{df}$ & & & & 1 & & 1 & 1 & & 1 & & \\
\hline & Deviance & & & & 20.0 & & 3.8 & 9.6 & & 9.0 & & \\
\hline & Residual df & 8683 & & & 8681 & 1703 & 1702 & 1701 & 25 & 24 & & \\
\hline & Residual deviance & 1870.6 & & & 1720.6 & 307.4 & 303.6 & 294 & 39.1 & 30.1 & & \\
\hline & $P$ & $<0.005$ & & & $<0.005$ & $<0.005$ & $<0.005$ & $<0.005$ & $<0.005$ & 0.003 & & \\
\hline
\end{tabular}

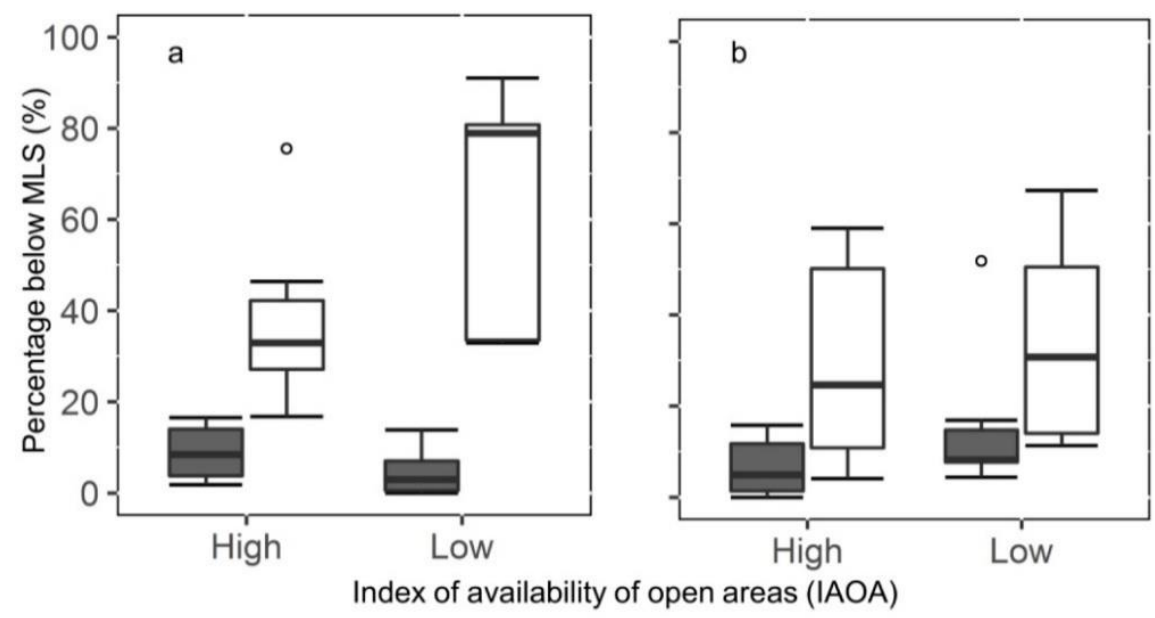

Figure 5. Boxplots depicting the percentage of a) loco (Concholepas concholepas), b) keyhole limpets (Fissurella spp.) extracted below minimum legal size (MLS) at sites with a high and low index of availability of open areas (IAOA). Dark gray boxplots indicate management areas, and white boxplots indicate open access areas. The outliers (white circles) identified in the figure belong to Papudo for open access areas in the case of the loco and Chungungo open access areas for keyhole limpets.

between management regimes, indicating that harvesting occurs on the cusp of the MLS. Nevertheless, the significant correlation between the fractions of the undersized catch of both species in OAAs suggests that MLS violations seem to occur in both species, allowing advanced explanatory hypotheses.

At least three plausible hypotheses can be proposed to explain the patterns observed along the study area for both species:

a) enforcement effectiveness provided by enforcement officers; b) market opportunities; and c) variability in social capital, environmental attitudes and norm internalization related to the experience of comanagement of MAs among coves (which involve enforcement of regulations in MA) (e.g., Gelcich et al., 2013) and consequent reciprocity with other management rules in OAAs (Marín et al., 2012). These hypotheses provide interesting bases to analyze how to reach equitable, efficient and adequate management of area-based instruments (Gill et al., 2017). 
Alternative area-based conservation measures, such as TURFs and multiple-use marine areas, clearly contribute to the protection of the ocean (Lester \& Halpern, 2008; Lester et al., 2009; Sala et al., 2018) and compensate for the imbalances in reaching international marine conservation goals (Butchart et al., 2015; Gill et al., 2017). The imbalance is particularly critical for the most threatened and least protected marine ecosystems, such as the coastal ocean (Kuempel et al., 2019). Chile is a clear example, with $1 \%$ of the coastal ocean protected where the artisanal benthic fisheries operate, compared to $40 \%$ in oceanic waters. It is in the nonprotected sea, the open-access areas, where we find the most considerable magnitude of MLS violations, calling attention to the need for effective enforcement. It is important to remark that any loco catch in an OAA is illegal since a complete ban has been in place for almost 30 years. However, loco harvesting in OAAs occurs regularly, with $50 \%$ of the catch comprised by individuals that have not reached the MLS. Although fishing keyhole limpets is a legal activity in OAAs, one-third of the keyhole limpet catch in OAAs is also made up of undersized individuals. Nevertheless, 90\% of the fishers claim to follow the existing size limits for benthic resources (Gelcich et al., 2009). The different results between the interviews and our direct assessment cannot be explained by the lack of fisher ability to assess MLS since the consistent pattern in the size structure of the catch for both species between management regimes suggests an evident ability to evaluate MLS visually.

Despite the benefits of MAs observed in this study and others (Gelcich et al., 2012; Pérez-Matus et al., 2017), we recognize that the MA system is far from perfect. From a fisher's perspective, expectations of the economic benefits have not been fully met (Gelcich $e t$ $a l ., 2017)$, as it is reflected in the high rate of MAs turnover, the increasing effort in OAAs (Beckensteiner et al., 2019) as well as illegal fishing in both management regimes. Recent studies showed that 50\% of fishers recognize being involved in the illegal exploitation of loco in MAs (Oyanedel et al., 2018), but the magnitude of illegal fishing is greater in OAAs. Remarkably, $100 \%$ of the divers claim to exploit loco in OAAs in central Chile (Oyanedel et al., 2018). These results match the patterns of total mortality; loco mortality in OAAs was $42 \%$ higher than in MAs, and keyhole limpet mortality was twice as high in OAAs as in MAs (Andreu-Cazenave et al., 2017). We show here that the fraction of the undersized catch in OAAs also duplicates the fraction observed in MAs. Indeed, poor enforcement in OAAs facilitates illegal fishing, but the influence of effort displacement cannot be ignored.

The consistent and contrasting patterns of the median size and fraction of undersized catch, obtained between MAs and OAAs located around coves with low availability of open access fishing grounds, suggest the influence of effort displacement. The percentage of the catch below the loco MLS in OAAs within regions with low IAOA was double that of the observed within regions with high IAOA, and a median size smaller. Although with smaller differences, a similar trend was observed in keyhole limpets. Thus, our on-the-ground analyses show the tremendous impact of enforcement and effort displacement, which we cannot directly separate but have inferred indirectly by comparing both groups of coves and both regimes. If enforcement was the most relevant or unique factor, the significant correlation in the fraction of undersized catch between limpets and loco observed in open-access fishing grounds should have also occurred in MAs. However, in MAs, the correlation was not significant. Moreover, a correlation in the level of compliance with the MLS regulation (fraction of undersized individuals) should be expected between management regimes if enforcement were the dominant driver. Still, the correlation was not significant (Spearman Rho $=-0.17$, $P=0.588$ ). Therefore, we conclude that the fraction of the coast assigned to area-based management tools, which affects the availability of fishing grounds for fishers, is a significant determinant of the fraction of illegal fishing in OAAs. The benefits of MAs inside the area of protection (Gelcich et al., 2012; Pérez-Matus et al., 2017) are questionable at the seascape scale. So far, all the indicators show that MAs perform better locally not only on the target resources but also on habitat structure and species richness (Techeira et al., 2010; Pérez-Matus et al., 2017). The fishing effort on carnivores, such as loco and fish species, has important cascading effects on the kelp ecosystem affecting the structure of the forest as well as diversity (Pérez-Matus et al., 2017). However, the contrast we observed on the outside is not independent of the pressure that protected areas and MAs (= TURFs) exert on their surroundings. This finding is not only locally relevant but also contributes to the discussion on how much of the ocean can be protected to reach healthy ecosystems beyond protected area limits. It also highlights the need to manage effort displacement levels in designing management and conservation area-based instruments.

Finally, our results highlight the relevance of focusing on the influence of illegal fishing in artisanal fisheries, using a study case from central Chile. It is critical to expanding the current national and international efforts to quantify and regulate illegal fishing in large-scale industrial fisheries to include small-scale artisanal fisheries. Artisanal fisheries currently account for $30 \%$ of total world catch, $50 \%$ of the entire landing for human consumption, and $90 \%$ of 
all fishers. Instruments recognizing and incorporating the nature of artisanal fisheries need to be developed or adapted to prevent illegal, unregulated and unreported fishing since existing tools such as binding instruments, code of conduct for responsible fisheries, or sophisticated technological tools, might not be easily applied to artisanal fisheries.

\section{ACKNOWLEDGMENTS}

This work was funded by Fondecyt (Project 1171603). The authors thank Marcela Lima and María Josefina Fernández for their help in data collection. We are also very grateful to the fishermen of the study area who kindly supported this study, and we also appreciate the comments of Katalin Plummer.

\section{REFERENCES}

Abbott, J.K. \& Haynie, A.C. 2012. What are we protecting? Fisher behavior and the unintended consequences of spatial closures as a fishery management tool. Ecological Applications, 22: 762-777. doi: 10.1890/11-1319.1

Aburto, J., Gallardo, G., Stotz, W., Cerda, C., MondacaSchachermayer, C. \& Vera, K. 2013. Territorial user rights for artisanal fisheries in Chile - intended and unintended outcomes. Ocean \& Coastal Management, 71: 284-295. doi.: 10.1016/j.ocecoaman.2012.09.015

Agnew, D.J., Pearce, J., Pramod, G., Peatman, T., Watson, R., Beddington, J.R. \& Pitcher, T.J. 2009. Estimating the worldwide extent of illegal fishing. Plos One, 4(2): e4570. doi: 10.1371/journal.pone.0004570

Anderson, M.J., Gorley, R.N. \& Clarke, K.R. 2008. PERMANOVA+ for PRIMER. Guide to software and statistical methods. PRIMER-E Ltd., Plymouth.

Andreu-Cazenave, M., Subida, M.D. \& Fernández, M. 2017. Exploitation rates of two benthic resources across management regimes in central Chile: evidence of illegal fishing in artisanal fisheries operating in open access areas. Plos One, 12(6): e0180012. doi: 10.1371/journal.pone0180012

Attwood, C.G. \& Bennett, B.A. 1995. Modelling the effect of marine reserves on the recreational shore-fishery of the south-western Cape, South Africa. South African Journal of Marine Science, 16: 227-240. doi: 10.2989/ 025776195784156458

Badin, R.M. \& Quiñones, R.A. 2014. Impacto de la captura ilegal en pesquerías artesanales bentónicas bajo el régimen de co-manejo: el caso de Isla Mocha, Chile. Latin American Journal of Aquatic Research, 42(3): 547-579. doi: 103856/vol42-issue3-fulltext-14
Beckensteiner, J., Scheld, A.M., Fernández, M. \& Kaplan, D.M. 2019. Drivers and trends in catch of benthic resources in Chilean TURFs and surrounding open access areas. Ocean and Coastal Management, 104961. doi: 10.1016/j.ocecoaman.2019.104961

Blank, S.G., \& Gavin, M.C. 2009. The randomized response technique as a tool for estimating noncompliance rates in fisheries: a case study of illegal red abalone (Haliotis rufescens) fishing in northern California. Environmental Conservation, 36(2): 112119. doi:10.1017/ S037689290999004X

Bohnsack, J.A. 2000. A comparison of the short-term impacts of no-take marine reserves and minimum size limits. Bulletin of Marine Science, 66(3): 635-650.

Bray, K. 2000. A global review of illegal, unreported and unregulated (IUU) fishing. FAO, Rome. [http:// www.fao.org/3/Y3274E/y3274e08.htm]. Reviewed: October 16, 2019.

Brown, D., González, M.L., López, D. \& Durán, L. 1997. Estudio de los ciclos vitales de las especies comerciales del genero Fissurella en las regiones I a X. Proyecto FIP 94-33. Universidad de Valparaíso, Valparaíso, 196 pp.

Butchart, S.H.M., Clarke, M., Smith, R.J., Sykes, R.E., Scharlemann, J.P.W., Harfoot, M. et al. 2015. Shortfalls and solutions for meeting national and global conservation area targets. Conservation Letters, 8(5): 329-337. doi: 10.1111/conl.12158

Cabral, R.B., Mayorga, J., Clemence, M., Lynham, J., Koeshendrajana, S., Muawanah, U., Nugroho, D., Anna, Z., Mira, Ghofar, A., Zulbainarni, N., Gaines, S.D. \& Costello, C. 2018. Rapid and lasting gains from solving illegal fishing. Nature Ecology \& Evolution, 2: 650-658. doi: 10.1038/s41559-018-0499-1

Castilla, J.C. \& Duran, L.R. 1985. Human exclusion from the rocky intertidal zone of central Chile: the effects on Concholepas concholepas (Gastropoda). Oikos, 45: 391-399. doi: 10.2307/3565575

Castilla, J.C. \& Fernández, M. 1998. Small-scale benthic fisheries in Chile: on co-management and sustainable use of benthic invertebrates. Ecological Applications, 8(1): S124-S132. doi: 10.1890/1051-0761(1998)8 [s124:sbfico]2.0.co;2

Castilla, J.C., Manriquez, P., Alvarado, J., Rosson, A., Pino, C. \& Espoz, C. 1998. Artisanal "Caletas" as units of production and co-managers of benthic invertebrates in Chile. Canadian Special Publications in Fisheries and Aquatic Sciences, 125: 407-413.

Castilla, J.C. \& Gelcich, S. 2008. The management of the loco (Concholepas concholepas) as a driver for selfgovernance of small-scale benthic fisheries in Chile. FAO Fisheries Technical Paper, 504: 441-451. 
Catchpole, T.L., Gray, T.S. \& Frid, C.L.J. 2002. Factors influencing discarding patterns, a case study of the English northeast coast Nephrops norvegicus fishery. International Council for the Exploration of the Sea (ICES) CM/V:06.

Costello, C., Ovando, D., Holborn, R., Gaines, S.D., Deschenes, O. \& Lester, S.E. 2012. Status and solutions for the world's unassessed fisheries. Science, 338(6106): 517-520. doi: 10.1126/science. 1223389

Drammeh, O.K.L. 2000. Illegal, unreported \& unregulated fishing in small-scale marine and Inland capture fisheries. [https://www.oceandocs.org/bitstream/handle/ 1834/776/IUU_2000.pdf? sequence=1]. Reviewed: October 15, 2019.

E Costa, B.H., Batista, M.I., Gonçalves, L., Erzini, K., Caselle, J.E., Cabral, H.N. \& Gonçalves, J. 2013. Fishers' behaviour in response to the implementation of a marine protected area. Plos One, 8(6): e65057. doi: 10.1371/journal.pone.0065057

Fernández, M. \& Castilla, J.C. 2005 Marine conservation in Chile: historical perspective, lessons, and challenges. Conservation Biology, 19(6): 1752-1762. doi: 10.1111/j.1523-1739.2005. 00277.x

Fernández, M., Blanco, M., Ruano, C. \& Subida, M.D. 2017. Reproductive output of two benthic resources (Fissurella latimarginata and Loxechinus albus) under different management regimes along the coast of central Chile. Latin American Journal of Aquatic Research, 45(2): 391-402. doi: 10.3856/vol45-issue2fulltext-14

Food and Agriculture Organization of the United Nations (FAO). 2017. Illegal, unreported and unregulated fishing-FAO compliance agreement. FAO, Rome. [http://www.fao.org/iuu-fishing/international-framework/fao-compliance-agreement/en/]. Reviewed: November 4, 2019.

Food and Agriculture Organization of the United Nations (FAO). 2018. El estado mundial de la pesca y la acuicultura 2018. Cumplir los objetivos de desarrollo sostenible. FAO, Rome. [http://www.fao.org/state-offisheries-aquaculture/es/]. Reviewed: November 4, 2019.

Forcada, A., Valle, C., Sánchez-Lizaso, J.L., BayleSempere, J.T. \& Corsi, F. 2010. Structure and spatiotemporal dynamics of artisanal fisheries around a Mediterranean marine protected area. ICES Journal of Marine Science, 67: 191-203. doi: 10.1093/icesjms/ fsp234

Gallardo-Fernández, G.L. \& Friman, E. 2011. New marine commons along the Chilean coast - the management areas (MAs) of Peñuelas and Chigualoco. International
Journal of the Commons, 5(2): 433-458. doi: $10.18352 / \mathrm{ijc} .284$

Gavin, M.C., Solomon, J.N. \& Blank, S.G. 2010. Measuring and monitoring illegal use of natural resources. Conservation Biology, 24(1): 89-100. doi: 10.1111/j.1523-1739.2009.01387.x

Gelcich, S., Godoy, N. \& Castilla, J.C. 2009. Artisanal fishers' perceptions regarding coastal co-management policies in Chile and their potentials to scale-up marine biodiversity conservation. Ocean \& Coastal Management, 52(8): 424-432. doi: 10.1016/j.ocecoaman. 2009.07.005

Gelcich, S., Hughes, T.P., Olsson, P., Folke, C., Defeo, O., Fernández, M., Foale, S., Gunderson, L.H., Rodríguez-Sickert, C., Scheffer, M. \& Steneck, RS. 2010. Navigating transformations in governance of Chilean marine coastal resources. Proceedings of the National Academy of Sciences, 107: 16794-16799. doi: 10.1073/pnas.1012021107

Gelcich, S., Fernández, M., Godoy, N., Canepa, A., Prado, L. \& Castilla, J.C. 2012. Territorial user rights for fisheries as ancillary instruments for marine coastal conservation in Chile. Conservation Biology, 26(6): 1005-1015. doi: 10.1111/j.1523-1739.2012.01928.x

Gelcich, S., Guzman, R., Rodríguez-Sickert, C., Castilla, J.C. \& Cárdenas, J.C. 2013. Exploring external validity of common-pool resource experiments: insights from artisanal benthic fisheries in Chile. Ecology and Society, 18(3): 2. doi: 10.5751/ES05598-180302

Gelcich, S., Cinner, J., Donlan, C.J., Godoy, N. \& Castilla, J.C. 2017. Fishers' perceptions on the Chilean coastal TURF system after two decades: problems, benefits, and emerging needs. Bulletin of Marine Science, 93(1): 53-67. doi: 10.5343/bms.2015.1082

Gill, D.A., Mascia, M.B., Ahmadia, G.N., Glew, L., Lester, S.E., Barnes, M., et al. 2017. Capacity shortfalls hinder the performance of marine protected areas globally. Nature Publishing Group, 543(7647): 665-669. doi: 10.1038/nature21708

González, J., Stotz, W., Garrido, J., Orensanz, J.M., Parma, A.M., Tapia, C. \& Zuleta, A. 2006. The Chilean TURF system: how is it performing in the case of the loco fishery? Bulletin of Marine Science, 78(3): 499-527.

Halpern, B.S. 2003. The Impact of marine reserves: Do reserves work and does reserve size matter? Ecological Applications, 13(1): 117-137.

Halpern, B.S., Gaines, S.D. \& Warner, R.R. 2004. Confounding effects of the export of production and the displacement of fishing effort from marine reserves. Ecological Applications, 14: 1248-1256. 
Hilborn, R., Orensanz, J.M.L. \& Parma, A.M. 2005. Institutions, incentives and the future of fisheries. Philosophical Transactions of the Royal Society of London B: Biological Sciences, 360(1453): 47-57. doi: $10.1098 /$ rstb.2004.1569

Kuempel, C., Jones, K., Watson, J. \& Possingham, H. 2019. Quantifying biases in marine-protected-area placement relative to abatable threats. Conservation Biology, 33(6): 1350-1359. doi: 10.1111/cobi.13340

Kuperan, K. \& Sutinen, J.G. 1998. Bluewater crime: deterrence, legitimacy, and compliance in fisheries. Law \& Society Review, 32(2): 309-338. doi: 10.2307/ 827765

Leiva, G.E. \& Castilla, J.C. 2002. A review of the world marine gastropod fishery: evolution of catches, management and the Chilean experience. Reviews in Fish Biology and Fisheries, 11: 283-300. doi: 10.1023/ A:1021368216294

Lester, S.E. \& Halpern, B.S. 2008. Biological responses in marine no-take reserves versus partially protected areas. Marine Ecology Progress Series, 367: 49-56. doi: 10.3354/meps07599

Lester, S.E., Halpern, B.S., Grorud-Colvert, K., Lubchenco, J., Ruttenberg, B.I., Gaines, S.D., Airamé, S. \& Warner, R.R. 2009. Biological effects within notake marine reserves: a global synthesis. Marine Ecology Progress Series, 384: 33-46. doi: 10.3354/ meps08029

Ley General de Pesca. 2013. [http://www.subpesca.cl/ portal/615/w3-article-88020.html]. Reviewed: March 16,2020

Manríquez, P.H., Delgado, A.P., Jara, M.E. \& Castilla, J.C. 2008. Field and laboratory pilot rearing experiments with early ontogenic stages of Concholepas concholepas (Gastropoda: Muricidae). Aquaculture, 279: 99-107. doi: 10.1016/j.aquaculture. 2008.03.031

Marín, A., Gelcich, S., Castilla, J.C. \& Berkes, F. 2012. Exploring social capital in Chile's coastal benthic comanagement system using a network approach. Ecology and Society, 17(1): 13. doi: 10.5751/ES04562-170113

McKinlay, J.P. \& Millington, P.J. 2000. Fisher obligations in co-managed fisheries: the case for enforcement. In: Shotton, R. (Ed.). Use of property rights in fisheries management. FAO, Rome, pp. 405-414. doi: 10.1016/ j.aquaculture.2008.03.031

Mora, C., Myers, R.A., Coll, M., Libralato, S., Pitcher, T.J., Sumalia, R.U., Zeller, D., Watson, R., Gaston, K.J. \& Worm, B. 2009. Management effectiveness of the world's marine fisheries. Plos Biology, 7(6): e1000131. doi: 10.1371/journal.pbio.1000131

Murawski, S.A., Wigley, S.E., Fogarty, M.J., Rago, P.J. \& Mountain, D.G., 2005. Effort distribution and catch patterns adjacent to temperate MPAs. ICES Journal of Marine Science, 62: 1150-1167. doi: 10.1016/j.icesjms.2005.04.005

Nahuelhual, L., Saavedra, G., Blanco, G., Wesselink, E., Campos, G. \& Vergara, X. 2018. On super fishers and black capture: Images of illegal fishing in artisanal fisheries of southern Chile. Marine Policy, 95: 36-45. doi: 10.1016/j.marpol.2018.06.020

Neubauer, P., Jensen, O.P., Hutchings, J.A. \& Baum, J.K. 2013. Resilience and recovery of overexploited marine populations. Science, 340(6130): 347-349. doi: 10.1126/science. 1230441

Nielsen, J.R. \& Mathiesen, C. 2003. Important factors influencing rule compliance in fisheries lessons from Denmark. Marine Policy, 27: 409-416. doi: 10.1016/ S0308-597X(03)00024-1

Oyanedel, R., Keim, A., Castilla, J.C. \& Gelcich, S. 2018. Illegal fishing and territorial user rights in Chile. Conservation Biology, 32(3): 619-627. doi: 10.1111/ cobi. 13048

Pauly, D. \& Zeller, D. 2016. Catch reconstructions reveal that global marine fisheries catches are higher than reported and declining. Nature Communications, 7: 10244. doi: 10.1038/ncomms 10244

Pauly, D. \& Zeller, D. 2017. Comments on FAOs state of world fisheries and aquaculture (SOFIA 2016). Marine Policy, 77: 176-181. doi: 10.1016/j.marpol.2017.01. 006

Pérez-Matus, A., Carrasco, S., Gelcich, S., Fernández, M. \& Wieters, E. 2017. Exploring the effects of fishing pressure and upwelling intensity over subtidal kelp forest communities in central Chile. Ecosphere, 8(5): e01808. doi: 10.1002/ecs2.1808

Poblete, E.G., Cerda, R., Quezada, J., Martínez, G., López, E., Thomas, F. \& Merino, J. 2013. Propuesta de política pública de desarrollo productivo para la pesca artesanal. Estudio para la determinación de una propuesta de política pública de desarrollo productivo para la pesca artesanal. [http://www.subpesca.cl/ portal/618/articles-80500_recurso_1.pdf]. Reviewed: October 7, 2019.

R Core Team. 2018. R: a language and environment for statistical computing version 3.5.1. $\mathrm{R}$ foundation for statistical computing. [http://www.R-project.org/]. Reviewed: October 12, 2019.

Raemaekers, S., Hauck, M., Bürgener, M., Mackenzie, A., Maharaj, G., Plagányi, É.E. \& Britz, P.J. 2011. Review of the causes of the rise of the illegal South African abalone fishery and consequent closure of the rightsbased fishery. Ocean \& Coastal Management, 54(6): 433-44. doi: 10.1016/j.ocecoaman.2011.02.001 
Ramorino, L. 1979. Conocimiento científico actual sobre reproducción y desarrollo de Concholepas concholepas (Mollusca: Gastropoda: Muricidae). Biología Pesquera, 12: 59-70.

Ruano, C., Subida, M.D. \& Fernández, M. 2017. Fishers' perception: an alternative source of information to assess the data-poor benthic small-scale artisanal fisheries of central Chile. Ocean and Coastal Management, 146: 67-76. doi: 10.1016/j.ocecoaman. 2017.06.007

Sala, E., Lubchenco, J., Grorud-Colvet, K., Novelli, C., Roberts, C. \& Sumaila, R. 2018. Assessing real progress towards effective ocean protection. Marine Policy, 91: 11-13. doi: 10.1016/j.marpol.2018.02.004

Salas, S., Chuenpagdee, R., Seijo, J.C. \& Charles, A. 2007. Challenges in the assessment and management of small-scale fisheries in Latin America and the Caribbean. Fisheries Research, 87: 5-16. doi: 10.1016/ j.fishres.2007.06.015

Servicio Nacional de Pesca (SERNAPESCA). 2016. Anuario 2016 - subsector pesquero artesanal. SERNAPESCA, Valparaíso. [http://ww2.sernapesca.cl/index.php?option=com_remository\&Itemid $=24$ $6 \&$ func=fileinfo\&id=26187]. Reviewed: October 23, 2019.

Servicio Nacional de Pesca (SERNAPESCA). 2019. Fiscalización en pesca y acuicultura. Informe de actividades del 2018. SERNAPESCA, Valparaíso. [http://www.sernapesca.cl/sites/default/files/informe_ actividades_de_fiscalizacion_sernapesca_2018_1.pdf]. Reviewed: September 3, 2019.

Solomon, J.N., Gavin, M.C. \& Gore, M.L. 2015. Detecting and understanding non-compliance with conservation rules. Biological Conservation, 189: 1-4. doi: 10.1016/j.biocon.2015.04.028

Stelzenmüller, V., Maynou, F., Bernard, G., Cadiou, G., Camilleri, M., Crec'hriou, R., Criquet, G., Dimech, M., Esparza, O., Higgins, R., Lenfant, P. \& PérezRuzafa, Á. 2008. Spatial assessment of fishing effort around European marine reserves: implications for successful fisheries. Marine Pollution Bulletin, 56: 2018-2026. doi: 10.1016/j.marpolbul.2008.08.006

Stergiou, K.I., Moutopoulos, D.K. \& Armensis, G. 2009. Perish legally and ecologically: the ineffectiveness of the minimum landing sizes in the Mediterranean Sea. Fisheries Management and Ecology, 16(5): 368-375. doi: 10.1111/j.1365-2400.2009.00672.x

Received: 11 November 2019; Accepted: 6 March 2020
Stotz, W. 2018. La experiencia de Chile en estudios de ecología de comunidades aplicados al aprovechamiento sostenible y conservación de la biodiversidad marino costera: el difícil camino hacia una armonía entre el ambiente, los pescadores y las regulaciones en la pesca artesanal de buceo en Chile. Revista Comunicaciones Científicas y Tecnológicas, 4(1): 275-285.

Stratoudakis, Y., Fryer, R.J. \& Cook, R.M. 1998. Discarding practices for commercial gadoids in the North Sea. Canadian Journal of Fisheries and Aquatic Sciences, 55: 1632-1644. doi: 10.1139/f98-029

Subsecretaría de Pesca y Acuicultura (SUBPESCA). 2019. Informe sectorial de pesca y acuicultura. Departamento de análisis sectorial. SUBPESCA, Valparaíso. [http://www.subpesca.cl/portal/616/articles-104821_documento.pdf]. Reviewed: September 19, 2019.

Techeira, C., Wilson, A., Bazán, V., Valdenegro, A., Torres, R., Álvarez, L., Palta, E., Cortés, C., Díaz, L. \& Aguilera, A. 2010. Investigación situación pesquerías bajo régimen de áreas de manejo 20092010. Informe final. IFOP, Valparaíso, $87 \mathrm{pp}$.

Tewfik, A. \& Béné, C. 2004. "The Big Grab": noncompliance with regulations, skewed fishing effort allocation and implications for a spiny lobster fishery. Fisheries Research, 69: 21-33. doi: 10.1016/j.fishres.2004.04.004

The World Bank. 2009. The sunken billions. The economic justification for fisheries reform. The International Bank for Reconstruction and Development/The World Bank, Washington DC. [https:// openknowledge.worldbank.org/bitstream/handle/1098 6/2596/476060PUB0Sunk101Official0Use0Only1.pd f?sequence=1\&isAllowed=y]. Reviewed: October 21, 2019.

Veiga, P., Pita, C., Rangel, M., Gonçalves, J.M., Campos, A., Fernandes, P.G. et al. 2016. The EU landing obligation and European small-scale fisheries: what are the odds for success? Marine Policy, 64: 64-71. doi: 10.1016/j-marpol.2015.11.008

Worm, B., Hilborn, R., Baum, J.K., Branch, T.A., Collie, J.S., Costello, C. et al. 2009. Rebuilding global fisheries. Science, 325(5940): 578-585. doi: 10.1126/ science. 1173146 